[Communication ]

\title{
Influence of Water on Adsorption Properties of Lithium Exchanged Low Silica X Zeolite*
}

\author{
Jiang Hua Zhao Bi-Ying Xie You-Chang \\ ( State Key Laboratory for Structural Chemistry of Unstable and Stable Species, College of Chemistry \\ and Molecular Engineering, Peking University, Beijing 100871)
}

\begin{abstract}
This paper shows quantitatively the consequence of adsorbed water on $\mathrm{N}_{2}$ or $\mathrm{O}_{2}$ adsorbed on LiLSX lithium exchanged low silica $\mathrm{X}$ zeolite. In the range of $0 \sim 32 \mathrm{H}_{2} \mathrm{O} /$ u. c. (unit cell), water present in LiLSX sharply declined the capacity for $\mathrm{N}_{2}$ or $\mathrm{O}_{2}$ adsorption. The reason is that the adsorption mainly occurs on the $\mathrm{Li}^{+}$ions on the 32 SIII sites in LiLSX. When $\mathrm{H}_{2} \mathrm{O}$ molecules residual after the desorption of hydrated LiLSX are adsorbed tightly on $\mathrm{Li}^{+}$ at SIII site, they block the adsorption of nitrogen or oxygen. Water molecules introduced from outside into the dehydrated LiLSX influenc the adsorption of nitrogen less seriously than the residual water molecules do, because of the heterogeneity of adsorption sites and the diffusion behavior of water in LiLSX. When diffused into the inner part of a LiLSX particle, some water molecules may adsorb on weaker sites other than the strongest SIII sites.
\end{abstract}

Keywords: Water, Adsorption, Air separation, Low silica X zeolite

Nitrogen and oxygen are widely used in industry. They are traditionally produced via air separation by cryogenic distillation. Since 1970s, PSA(pressure swing adsorption) or VPSA (vacuum pressure swing adsorption) has become new technologies to separate air, especially in middle and small scales production.

Synthetic zeolites 5A and faujasite $\mathrm{X}$ have been typically used as adsorbents for air separation. These adsorbents adsorb $\mathrm{N}_{2}$ more strongly than $\mathrm{O}_{2}$. The extraframework cations in the zeolites play a major role for the nitrogen adsorption selectivity. Because the quardruple moment of nitrogen is about 3 times that of oxygen, the interaction between the cations and nitrogen is much stronger. In 1989, Chao ${ }^{[1]}$ reported that low silica $\mathrm{X}$ ( $\mathrm{LSX}$ ) having a $\mathrm{Si} / \mathrm{Al}$ ratio of 1.0 with lithium exchange level greater than $70 \%$ showed unexpected high capacity for nitrogen adsorption. Two reasons account for the excellent performance of lithium $\operatorname{LSX}(\mathrm{LiLSX})$. First, $\mathrm{Li}^{+}$has the smallest radius, so its interaction with $\mathrm{N}_{2}$ is strong. Second, LSX has the lowest $\mathrm{Si} / \mathrm{Al}$ ratio, so that it can contain the uppermost amount of $\mathrm{Li}^{+}$. Now LiLSX is the best adsorbent for $\mathrm{O}_{2}$ manufacture by VPSA or PSA in industry.

It is well known that zeolites have a strong affinity for water, which greatly affects the adsorption of nonpolar molecules. This point is very important for the industrial use in air separation, for it was observed that a little water present in LiLSX sharply declined the capacity for $\mathrm{N}_{2}$ adsorption. In this paper, we show quantitatively the consequence of adsorbed water on air separation.

Sodium, potassium LSX (NaKLSX) was synthesized following the procedure reported by Kuhl ${ }^{[2]}$. LiLSX was prepared by five static ion exchange of NaKLSX at $100{ }^{\circ} \mathrm{C}$ with a 5. 6-fold equivalent excess

Received: March 11, 2002; Revised: April 4, 2002. Correspondent: Xie You-Chang(E-mail: yxie@ pku. edu. cn). * The Project Supported 


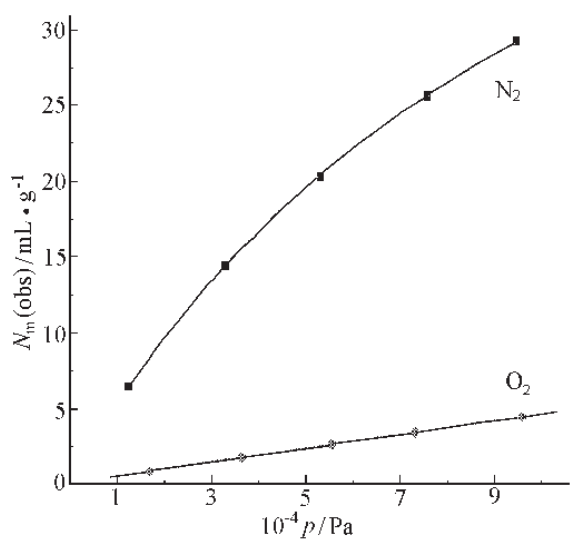

Fig. $1 \quad \mathrm{~N}_{2}$ and $\mathrm{O}_{2}$ adsorption isotherms at $25{ }^{\circ} \mathrm{C}$ on LiLSX

of $2.0 \mathrm{~mol} \cdot \mathrm{L}^{-1} \mathrm{LiCl}^{[3]}$. Previously, $\mathrm{LiOH}$ was added into the $\mathrm{LiCl}$ solution to adjust the $\mathrm{pH}$ to $8 \sim 10$. After the ion exchange, the sample was stirred with deionized water and filtered. This procedure was repeated until no $\mathrm{Cl}^{-}$was detected by $0.1 \mathrm{~mol} \cdot \mathrm{L}^{-1} \mathrm{AgNO}_{3}$. Finally, the obtained LiLSX was dried at $80{ }^{\circ} \mathrm{C}$. To analyze the composition of LiLSX, circa $0.2 \sim 0.3 \mathrm{~g}$ sample was decomposed using $\mathrm{HCl}$, then filtered and washed with deionized water until no $\mathrm{Cl}^{-}$residual on the filter cake. After being calcined at $800{ }^{\circ} \mathrm{C}$, the filter cake was turned into $\mathrm{SiO}_{2}$ and weighed. $\mathrm{Al}^{3+}$ in the filtrate was determined by complexometric titration. $\mathrm{Li}^{+}, \mathrm{Na}^{+}$and $\mathrm{K}^{+}$in the filtrate were analyzed by inductively coupled plasma-atomic emission spectroscopy (ICP-AES). Table 1 shows the results of element alanalysis for LiLSX.

The adsorption isotherms of $\mathrm{N}_{2}$ and $\mathrm{O}_{2}$ were measured using constant volume method. Fig. 1 shows the adsorption isotherms of $\mathrm{N}_{2}$ and $\mathrm{O}_{2}$ on dehydrated LiLSX, obtained by in situ pretreatment at $350{ }^{\circ} \mathrm{C}$ under vacuum $(\sim 8 \mathrm{~Pa})$ for $2 \mathrm{~h}$. The adsorption properties (Table 1) can be deduced from the isotherms and characterized by the following three

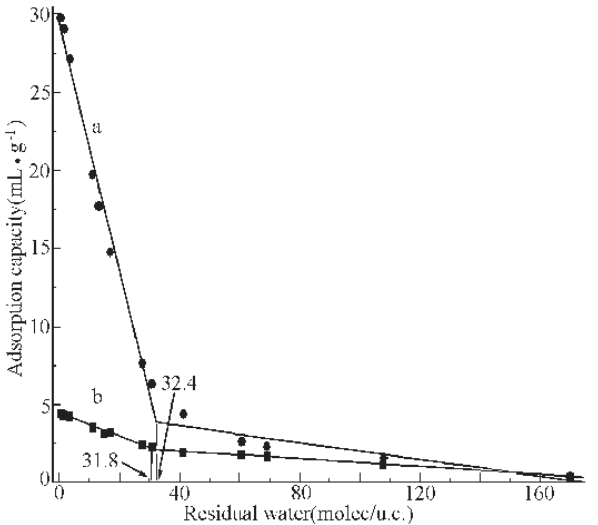

Fig. 2 Adsorption capacity versus residual water at $1.01 \times 10^{5} \mathrm{~Pa}, 298 \mathrm{~K}$

a) $\mathrm{N}_{2}$, b) $\mathrm{O}_{2}$

parameters ${ }^{[3]}$ :

$N_{\mathrm{m}}$ (obs): nitrogen adsorption capacity at $1.01 \times 10^{5}$ $\mathrm{Pa}, 25{ }^{\circ} \mathrm{C}$;

$N_{\mathrm{m}}$ (delta) : nitrogen working capacity $=\mathrm{N}_{2}$ adsorption capacity $\left(1.01 \times 10^{5} \mathrm{~Pa}\right)-\mathrm{N}_{2}$ adsorption capacity $\left(0.2 \times 1.01 \times 10^{5} \mathrm{~Pa}\right)$, at $25{ }^{\circ} \mathrm{C}$;

$\mathrm{S}\left(\mathrm{N}_{2} / \mathrm{O}_{2}\right): \mathrm{N}_{2} / \mathrm{O}_{2}$ selectivity $=\mathrm{N}_{2}$ adsorption capacity $\left(0.25 \times 1.01 \times 10^{5} \quad \mathrm{~Pa}\right) / \mathrm{O}_{2}$ adsorption capacity (0. $\left.25 \times 1.01 \times 10^{5} \mathrm{~Pa}\right)$

The samples with different water contents were prepared by heating at various temperatures from ambient temperature to $350{ }^{\circ} \mathrm{C}$ under vacuum. Then $\mathrm{N}_{2}$ and $\mathrm{O}_{2}$ adsorption isotherms were measured. Water contents were calculated from the weight loss supposing that the sample heated at $450{ }^{\circ} \mathrm{C}$ under $8 \mathrm{~Pa}$ contains no water, for the weight loss on this condition is in correspondence with that of the same sample calcined at $800{ }^{\circ} \mathrm{C}$. Fig. 2a shows the relationship between the $\mathrm{N}_{2}$ capacity and the residual water in the zeolites. At first, as the water content goes up, the $\mathrm{N}_{2}$ capacity drops sharply from 30 to $3.8 \mathrm{~mL} \cdot \mathrm{g}^{-1}$, then it descends much more slowly. Fig. $2 b$, which is the $\mathrm{O}_{2}$ capacity versus residual water, shows the same

Table 1 Nitrogen adsorption capacity and $\mathrm{N}_{2} / \mathrm{O}_{2}$ selectivity over LiLSX at $25{ }^{\circ} \mathrm{C}$

\begin{tabular}{cccccccc}
\hline Sample & $\mathrm{Si} / \mathrm{Al}$ & $\mathrm{Li} / \mathrm{Al}^{*}$ & $\mathrm{Na} / \mathrm{Al}$ & $\mathrm{K} / \mathrm{Al}$ & $N_{\mathrm{m}}($ obs $) / \mathrm{mL} \cdot \mathrm{g}^{-1}$ & $N_{\mathrm{m}}($ delta $) / \mathrm{mL} \cdot \mathrm{g}^{-1}$ & $\mathrm{~S}\left(\mathrm{~N}_{2} / \mathrm{O}_{2}\right)$ \\
\hline $\mathrm{LiLSX}^{* *}$ & 1.0 & 0.98 & 0 & 0 & 30.2 & 20.5 & 9.51 \\
\hline${ }^{*}$ molar ratio; & * "sample was activated at $450{ }^{\circ} \mathrm{C}, 8 \mathrm{~Pa}$ & & & &
\end{tabular}




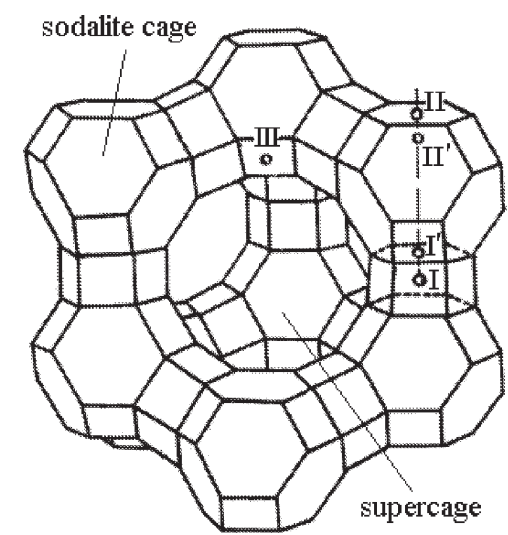

Fig. 3 Unit cell of faujasite zeolite and the distribution of cation sites

trend. Two figures reveal a common turn-point, viz about $32 \mathrm{H}_{2} \mathrm{O}$ molec. /u. c. (molecules per unit cell).

This result is in good agreement with that of Yang and co-workers reported ${ }^{[4]}$. Why the adsorption capacity of $\mathrm{N}_{2}$ and $\mathrm{O}_{2}$ drops sharply before the number of water in the LiLSX increases to 32 molec. /u. c. ? As we know, the unit cell of thoroughly exchanged LiLSX is $\mathrm{Li}_{96}\left(\mathrm{AlO}_{2}\right)_{96}\left(\mathrm{SiO}_{2}\right)_{96}$. Five cation sites exist as SI, SI', SII, SII' and SIII. The location of these sites are shown in Fig. 3. Feuerstein ${ }^{[5]}$ employed ${ }^{7} \mathrm{Li}$ MAS NMR to investigate the site population of $\mathrm{Li}^{+}$. Their results showed that $\mathrm{Li}^{+}$occupied $\mathrm{SI}^{\prime}$, SII and SIII by 32 each kind of site. SI' sites are located in $\beta$ cages which are sterically inaccessible to $\mathrm{N}_{2}$ or $\mathrm{O}_{2}$. SII sites are on the wall of a supercage. The small $\mathrm{Li}^{+}$at this site sits in the center of a six-membered oxygen ring. This allows the electric field generated by $\mathrm{Li}^{+}$to be nearly completely shielded. Besides, the six oxygen atoms in the ring prevent $\mathrm{N}_{2}$ and $\mathrm{O}_{2}$ from contacting the $\mathrm{Li}$ ions closely, so that $\mathrm{Li}$ ions at these sites can not adsorb $\mathrm{N}_{2}$ and $\mathrm{O}_{2}$. SIII sites are located near the four rings inside the supercage, which are in a high-energy state, low coordination environment. So only the $32 \mathrm{Li}^{+}$at SIII sites may interact with $\mathrm{N}_{2}$ or $\mathrm{O}_{2}$, that means each $\mathrm{Li}^{+}$at SIII site adsorbs about 0. $5 \mathrm{~N}_{2}$ molecule. It's obvious that the $\mathrm{Li}^{+}$at SIII sites also prefer to attract $\mathrm{H}_{2} \mathrm{O}$ molecules. Because of the very strong interaction between $\mathrm{H}_{2} \mathrm{O}$ and $\mathrm{Li}^{+}$, when $\mathrm{H}_{2} \mathrm{O}$ molecules are adsorbed on the $32 \mathrm{Li}^{+}$at SIII sites, they will block the adsorption of other molecules. This explains why it takes only $32 \mathrm{H}_{2} \mathrm{O}$ molecules to significantly diminish the $\mathrm{N}_{2}$ adsorption capacity.

Hereinbefore, we used hydrated LiLSX as starting material and removed water bit by bit to study the water effect on nitrogen adsorption. However, in the industrial application, dehydrated zeolites are the starting material, loaded in the bed. As time elapses, water in the air is adsorbed gradually and decreases the performance of VPSA or PSA. To simulate this case, we quantitatively introduced water into thoroughly dried LiLSX at ambient temperature. It can be seen from Fig. 4, when water amount was below about 7 molecules/u.c., the nitrogen capacity was almost the same in both cases. Yet above that amount, the nitrogen capacity was always higher in the latter case. After heating the samples in the latter case at temperatures much lower than their desorption temperatures of water, the nitrogen capacity dropped again to almost the same amount as that of the former case.

The phenomena can be explained by the heterogeneity of adsorption sites and the diffusion behavior

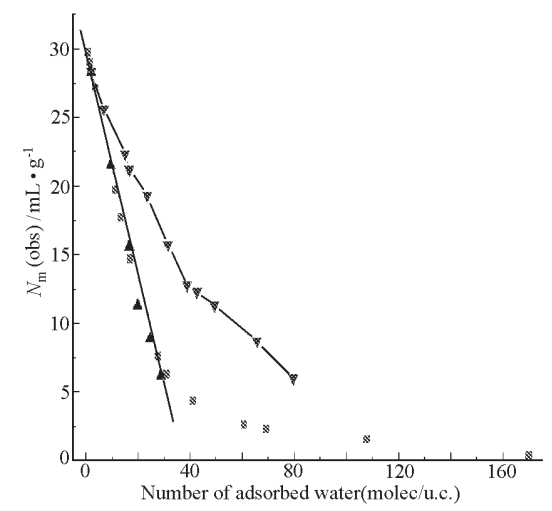

Fig. 4 Nitrogen adsorption capacity on various conditions of water adsorption at $1.01 \times$ $10^{5} \mathrm{~Pa}, 298 \mathrm{~K}$

- water remained after heating hydrated LiLSX

V water introduced from outside at ambient temperature

\ water introduced from outside then heated at temperature lower than desorption temperature 
of water in LiLSX. TPD results obtained by Hunger ${ }^{[6]}$ showed four desorption peaks for water adsorbed on lithium LSX, the desorption energies of which were $50,58,69$ and $85 \mathrm{~kJ} \cdot \mathrm{mol}^{-1}$, respectively. The number of water corresponding to the maximum desorption energy $\left(85 \mathrm{~kJ} \cdot \mathrm{mol}^{-1}\right)$ peak was about 29 molecules/u. c., quite near 32 molecules/u.c. Though thase authors didn't make designation to this peak, according to our results, we tentatively attribute it to water adsorbed on $\mathrm{Li}^{+}$at SIII site inside the supercages. When water molecules were introduced from outside, they were firstly adsorbed on the strongest sites, namely $\mathrm{Li}^{+}$at SIII sites, thus caused the sharp decrease of nitrogen capacity. Part of the subsequent water molecules were most likely adsorbed on other weaker sites before they could diffuse into the inner part of a LiLSX particle. Therefore, some $\mathrm{Li}^{+}$ at SIII sites located in the inner part of LiLSX remained intact, leading to the higher nitrogen capacity.
Heating the samples caused the migration of water molecules from the weaker sites to $\mathrm{Li}^{+}$at SIII sites so that the nitrogen capacity decreased again. That the water introduced from outside influences nitrogen adsorption less seriously provides for us a round understanding of the water effect and supplies some basic data for the industrial application.

\section{References}

1 Chao C C. Separating Nitrogen from Gas Mixtures-by Contacting with Lithium Exchanged Zeolite. US Patent. 4859217, 1989

2 Kuhl G H. Zeolites, 1987, 7: 451

3 Kirner J F. Nitrogen Adsorption with Highly Li Exchanged X-zeolites with Low Si/Al Ratio. US Patent. 5268023, 1993

4 Hutson N D, Zajic S C, Yang R T. Ind. Eng. Chem. Res., 2000, 39: 1775

5 Feuerstein M, Engelhardt G, McDaniel P L, MacDougall J E, Gaffney T R. Microporous and Mesoporous Materials, 1998, 26: 27

6 Hunger B, Klepel O, Kirschhock C, Heuchel M, Toufar H, Fuess H. Langmuir, 1999, 15: 5937

\title{
水对锂交换低硅铝比八面沸石吸附性能的影响*
}

\author{
蒋化赵壁英谢有畅 \\ (北京大学化学与分子工程学院,北京 100871)
}

\begin{abstract}
摘要 研究了变压吸附空气分离制氧吸附剂——锂交换低硅铝比八面沸石 LiLSX 中残留水及从外部引人 的水对吸附性能的影响. 研究表明, 在水合 LiLSX 经脱附后, 当残留的水分子数目为 $0 \sim 32$ (个分子/晶胞) 时, $\mathrm{N}_{2}$ 或 $\mathrm{O}_{2}$ 的吸附量下降显著. 原因是 $\mathrm{N}_{2}$ 和 $\mathrm{O}_{2}$ 的吸附主要依赖于处在 SIII 位置的 32 个锂离子. 当水分 子与 SIII 位置的 $\mathrm{Li}^{+}$结合时, 就会阻碍 $\mathrm{N}_{2}$ 或 $\mathrm{O}_{2}$ 的吸附. 而从外部引人的水分子与脱附残留的水分子相比, 在相同水含量时对吸附量的影响较小, 这是由于吸附位置的不均匀性以及水分子在沸石中的扩散行为所引 起. 在水扩散进人 LiLSX 内部的过程中, 一部分水分子可以吸附在能量较低的位置上而不是吸附到最强的 SIII 位置上。
\end{abstract}

关键词: 水, 吸附, 空气分离, 低硅铝比八面沸石 中图分类号: O647.3 